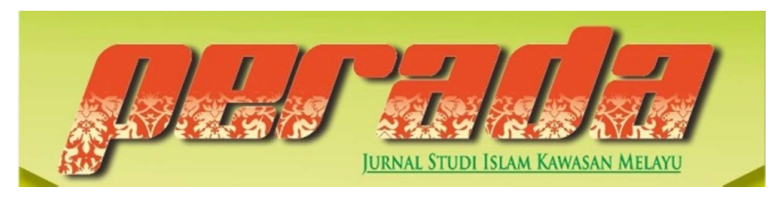

Perada: Jurnal Studi Islam Kawasan Melayu

ISSN 2656-7202 (P) ISSN 2655-6626 (0)

Volume 3 Nomor 2, Juli-Desember 2020

DOI: $\underline{\text { https://doi.org/10.35961/perada.v3i2.230 }}$

\title{
HADIS TENTANG NIAT DAN KORELASINYA TERHADAP MOTIVASI BAGI PESERTA DIDIK
}

\author{
Almahfuz \\ STAIN Sultan Abdurrahman Kepulauan Riau \\ almahfuz0411@gmail.com \\ Ilyas Husti \\ UIN Sultan Syarif Kasim Pekabaru \\ hilyashusti@yahoo.com \\ Alfiah \\ UIN Sultan Syarif Kasim Pekabaru \\ alfia@uinsuska.ac.id
}

\begin{abstract}
ABSTRAK
Belajar dan pembelajaran sangat dipengaruhi oleh niat dan motivasi. Oleh sebab itu, makalah ini bertujuan untuk menganalisa dan membahas hadis-hadis tentang niat dan melihat pengaruhnya tehadap motivasi belajar. Hasil menunjukkan bahwa hadis tentang niat ini dalam artikel ini memiliki kualitas sahih, baik dari segi sanad maupun matan, karena semua kriteria kesahihan termasuk bersambungnya sanad, perawinya 'adil dan dhabit, semuanya terpenuhi. Banyak ulama menekankan perlunya niat dalam setiap perbuatan karena menjadi bagian penting dalam melakukan sesuatu. Kuatnya nilai hadis tentang ini mendakan bahwa niat perlu dilakukan untuk setiap perbuatan yang mengandung nilai ibadah, termasuk dalam hal belajar. Dalam hal korelasi dengan motivasi siswa, secara konseptual juga terdapat koralasi antara tinggi rendahnya hasil belajar siswa ditentukan oleh tinggi rendahnya niat belajarnya. Siswa yang memiliki motivasi belajar yang tinggi, berlandaskan kepada niat dan dorongan untuk belajar semata-mata untuk memenuhi tuntunan agama berpotensi untuk lebih berhasil. Dengan niatan tulus dan motivasi yang kuat, upaya untuk belajar semakin teguh, apabila bila hal itu berlandaskan pada semangat beribadah disertai oleh ridha dari Allah.
\end{abstract}

Abstract: This article aims to analyze and discuss the traditions about intention and see their effect on learning motivation. The results show that the hadith about this intention in this article has a valid 
quality, both in terms of sanad and mind, because all the criteria of validity including the continuity of sanad, the perawinya 'fair and dhabit, are all fulfilled. Many scholars emphasize the need for intention in every action because it is an important part of doing something. The strong value of the hadith about this implies that an intention needs to be done for every act that contains worship value, including in terms of learning. In terms of correlation with student motivation, conceptually there is also a correlation between the high and low student learning outcomes determined by the level of learning intentions. Students who have high learning motivation, based on the intention and urge to study solely to fulfill religious guidance have the potential to be more successful. With sincere intentions and strong motivation, efforts to learn will be even stronger, if if it is based on the spirit of worship accompanied by the pleasure of Allah.

Kata Kunci : niat, mitivasi belajar, motivasi islami

\section{PENDAHULUAN}

Belajar dan pembelajaran sangat dipengaruhi oleh motivasi pada diri peserta didik, sebagaimana dalam beberapa literatur pendidikan Islam terutama yang berbahasa Arab, memaknai motivasi disepadankan dengan kata niyat. Pemikiran pendidikan Islam klasik mempunyai khazanah yang cukup luas membahas persoalan motivasi belajar ini, salah satunya adalah konsep niyat al-ta'allum (motivasi belajar) persfektif alJarnuzi dalam salah satu bukunya, Ta'lim alMuta'allim.

Ketika peserta didik menuntut ilmu semestinya memperhatikan beberapa hal yang perlu disadari dan disemayamkan dalam dirinya, diantaranya adalah harus memiliki niat yang bagus dan lurus serta ikhlas di dalam hatinya. Niat yang disematkan dalam hati semata-mata menuntut ilmu karena Allah ta'ala. Selain itu seorang peserta didik juga harus mempunyai motivasi yang kuat terutama motivasi yang bersifat intrensik yang bersumber dari dalam dirinya sendiri, meskipun tidak menutup kemungkinan dukungan motivasi yang bersifat ekstrensik dari luar dirinya dalam usahanya menuntut ilmu yang bermanfaat untuk kemaslahatan umat. Melalui motivasi yang kuat dengan mengharap ridho Allah niscaya akan membawa kemudahan ketika dalam proses pembelajaran, memeperoleh keberkahan ketika tercapai tujuan.
Kata hadis telah menjadi salah satu kosa kata bahasa Indonesia. Hadis adalah kata yang berasal dari bahasa Arab, yaitu alhadits jama'nya al-ahadits yang meiliki arti alkhabar yang dalam bahasa Indonesia bisa diartikan kabar atau berita. ${ }^{1}$ Sabda Rasulullah sendiri dari segi arti istilah dikemukakan secara teoritis hadis disebut juga dengan sunnah, merupakan sumber ajaran Islam yang berisi pernyataan, pengamalan, pengakuan dan hal ihwal Nabi Muhammad yang beredar pada masa Nabi Muhammad hingga wafatnya disepakati sebagai sumber ajaran Islam setelah Al-Qur'an dan isinya menjadi bujjah (sumber otoritas) keagamaan. ${ }^{2}$ Di sisi lain hadis Nabi merupakan penafsiran Al-Qur'an dalam praktek atau penerapan ajaran Islam secara faktual dan ideal.

Oleh karena kedudukan hadis sebagai sumber hukum kedua setelah Al-Qur'an, maka sudah menjadi keniscayaan bagi seluruh umat Islam untuk mempelajari secara konsen ilmu hadis agar dalam memahami suatu hadis tidak terjadi kesalahan dalam penafsirannya. Salah satu hadis yang sangat populer dan tidak asing di telinga kita, adalah hadis tentang niat yang diriwayatkan hampir oleh seluruh ulama

\footnotetext{
1 Sa'dullah Assa'idi, 'Hadis-Hadis Sekte', Yogyakarta: Pustaka Pelajar, 1996.

2 HM Erfan Soebahar, Menguak Fakta Keabsahan Al-Sunnah (Prenada Media, 2003), p. 3.
} 
hadis (kecuali Imam Malik) akan dibahas dalam makalah ini.

Dalam artikel ini akan dibahas tentang korelasi niat dengan motivasi belajar. Hal ini beranjak dari asumsi bahwa ketika seorang memiliki niat yang kuat dalam meraih sesuatu, maka kecenderungannya dari orang tersebut ialah akan berupaya kuat untuk meraihnya. Demikian juga dalam proses belajar bagi seorang siswa, maka apabila telah memiliki niat yang kuat tentunya akan diiringi dengan daya upaya serta usaha untuk melaksanakan niatnya. Niat bisa berupa motivasi yang mendorong siswa untuk mau belajar. Terdapat dua jenis motivasi, yaitu motivasi instrinsik dan ekstrinsik. Motivasi intrinsik yakni keadaan pada diri sendiri yang mendorongnya melakukan belajar sedangkan motivasi ekstrinsik yakni, faktor luar diri yang mendorongnya untuk melakukan kegiatan belajar. $^{3}$

Artikel ini akan mengupas hadis yang berkaitan dengan niat serta korelasinya dengan motivasi siswa dalam belajar. Kajian yang digunakan ialah kajian normatif filosofis, yakni kajian terhadap teks normatif agama yang termaktub dalam hadis dengan mencari nilai-nilai filosifis yang termuat di dalamnya. Kajian folosofis ini juga menjadi pendekatan dalam analisa terhadap motivasi siswa dalam belajar.

\section{SANAD DAN MATAN HADIS TENTANG NIAT}

Hadis-hadis tentang niat terdapat lafaz yang bervariasi, namun jika dicermati makna teksnya (matan hadis) terdapat substansi maksud yang sama, dengan mengetahui berbagai variasi sanad dan matan hadis tertentu sehingga dapat diketahui apakah berbeda jalur periwayatan atau tidak,

3 Amna Emda, 'Kedudukan Motivasi Belajar Siswa Dalam Pembelajaran', Lantanida Journal, 5.2 (2018), 172-82. ketentuan ada syahid dan muttabi'-nya dan seluruh jalur sanad yang diteliti. Adapun redaksi hadis-hadis yang berkaitan dengan motivasi niat terdapat dalam beberapa kitab hadis, dalam hal ini penulis akan menyertakan hadis- hadisnya sebagai berikut.

\section{A. Hadis Riwayat Bukhari}

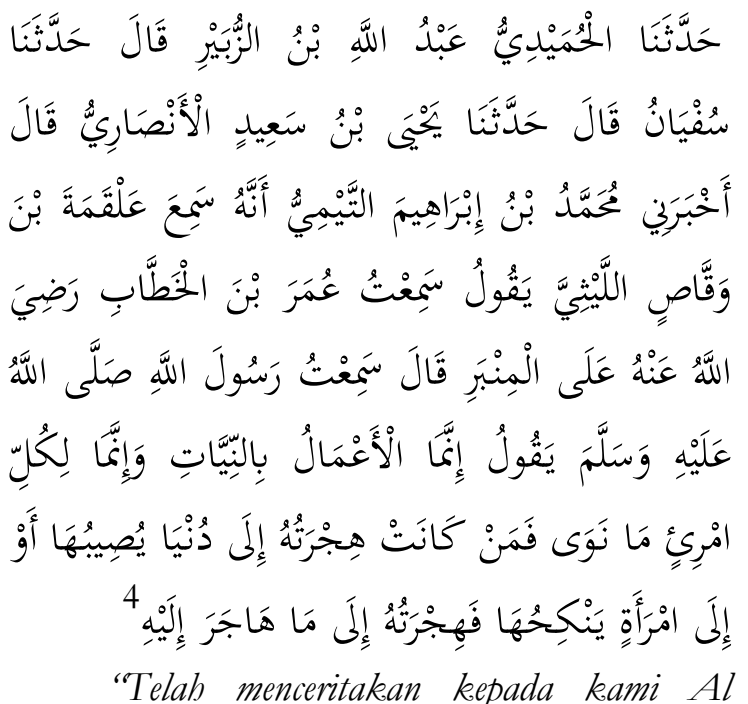
Humaidi Abdullab bin Az. Zubair dia berkata, Telah menceritakan kepada kami Sufyan yang berkata, babwa Telab menceritakan kepada kami Yabya bin Sa'id Al-Anshari berkata, telah mengabarkan kepada kami Mubammad bin Ibrahim At Taimi, babwa dia pernah mendengar Alqamah bin Waqash Al Laitsi berkata; saya pernah mendengar Umar bin Al Khaththab diatas mimbar berkata; saya mendengar Rasulullab shallallahu 'alaibi wasallam bersabda: "Semua perbuatan tergantung niatnya, dan (balasan) bagi tiap-tiap orang (tergantung) apa yang diniatkan; Barangsiapa niat hijrahnya karena dunia yang ingin digapainya atau karena seorang perempuan yang ingin dinikahinya, maka

4 Muhammad bin Isma'il bin Ibrahim AlBukhari, Shahib Al-Bukhari (Riyadh: Dar as-Salam, 1999), I, h. 3-4. 
hijrahnya adalah kepada apa dia diniatkan."

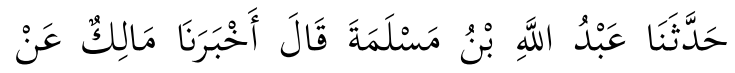

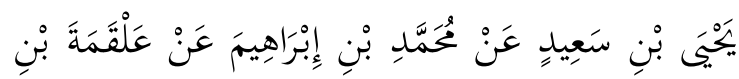

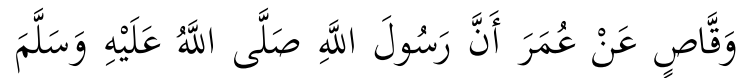

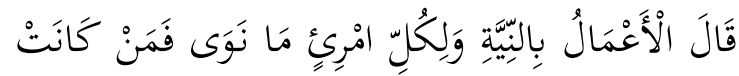

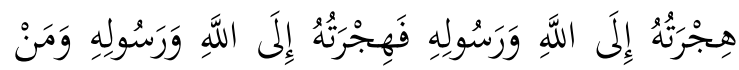

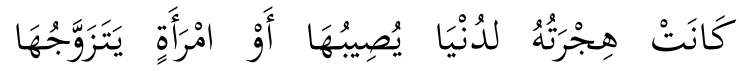

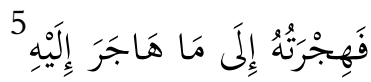

"Telah menceritakan kepada kami Abdullah bin Maslamah berkata, telah mengabarkan kepada kami Malik dari Yabya bin Sa'id dari Mubammad bin Ibrahim dari Alqamah bin Waqash dari Umar, bahwa Rasulullah shallallahu 'alaibi wasallam bersabda: "Semua perbuatan tergantung niatnya, dan (balasan) bagi tiap-tiap orang (tergantung) apa yang diniatkan; barangsiapa niat hijrahnya karena Allah dan Rasul-Nya, maka hijrahnya adalah kepada Allah dan Rasul-Nya. Barangsiapa niat hijrahnya karena dunia yang ingin digapainya atau karena seorang perempuan yang ingin dinikahinya, maka hijrahnya adalah kepada apa dia diniatkan."

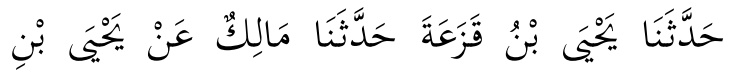

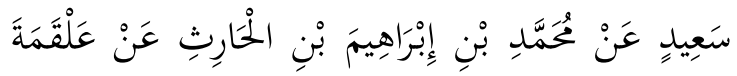

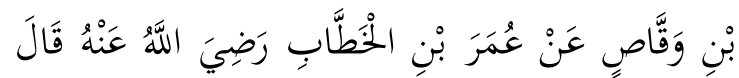

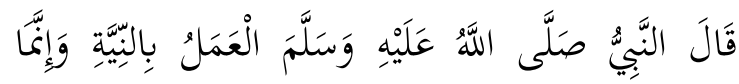
للامْرِيٍُ مَا نَوَى فَمَنْ كَانَتْ هِجْرَتُهُ إِلَى اللَّهِ وَرَسُولِِِ

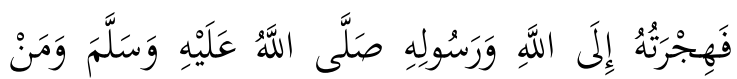

${ }^{5}$ Al-Bukhari, I, h. 23.

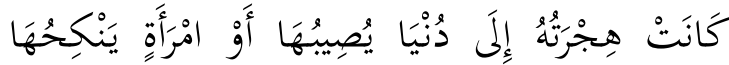

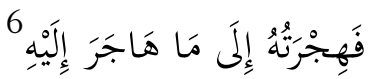

"Telah menceritakan kepada kami Yabya bin Qaza'ah. Telab menceritakan kepada kami Malik dari Yabya bin Sa'id dari Mubammad bin Ibrabim bin Al Harits dari 'Alqamah bin Waqash dari Umar bin Al Khatbthab radliallahu 'anbu ia berkata; Nabi shallallabu 'alaibi wasallam bersabda, "Sesungguhnya setiap amal itu tergantung pada niatnya. Dan bagi seseorang adalah apa yang ia niatkan. Barangsiapa yang hijrahnya kepada Allah dan Rasul-Nya, maka hijrahnya itu kepada Allah dan Rasul-Nya, dan barangsiapa yang hijrahnya lantaran dunia yang hendak ia kejar atau wanita yang ingin dinikahinya, maka hijrahnya itu adalah sekedar kepada apa yang ia inginkan."

\section{B. Hadis Riwayat Muslim}

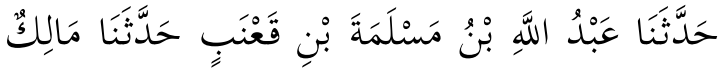

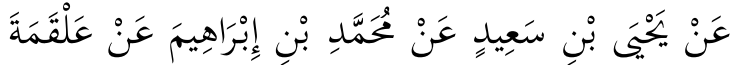

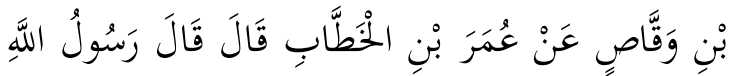

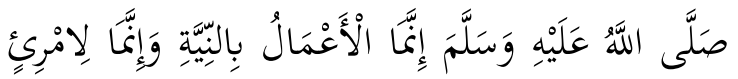

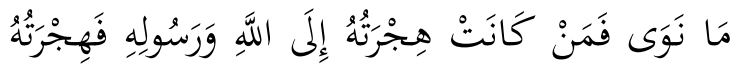
إِلَى اللَّهِ وَرَسُولِهِ وَمَنْ كَانَتْ هِجْرَتُهُ لِدُنْيَا يُصِيبُهَا أَوْ

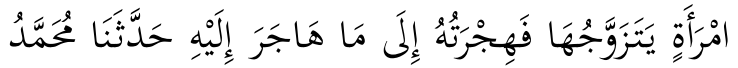

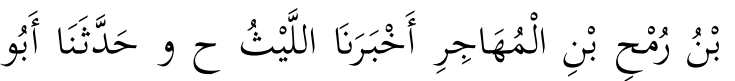

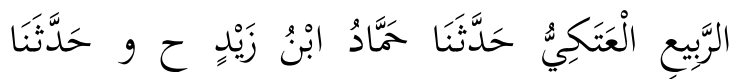

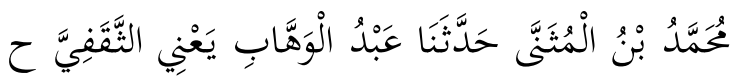

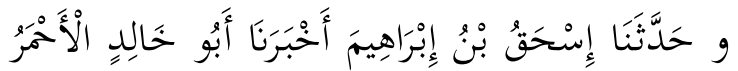




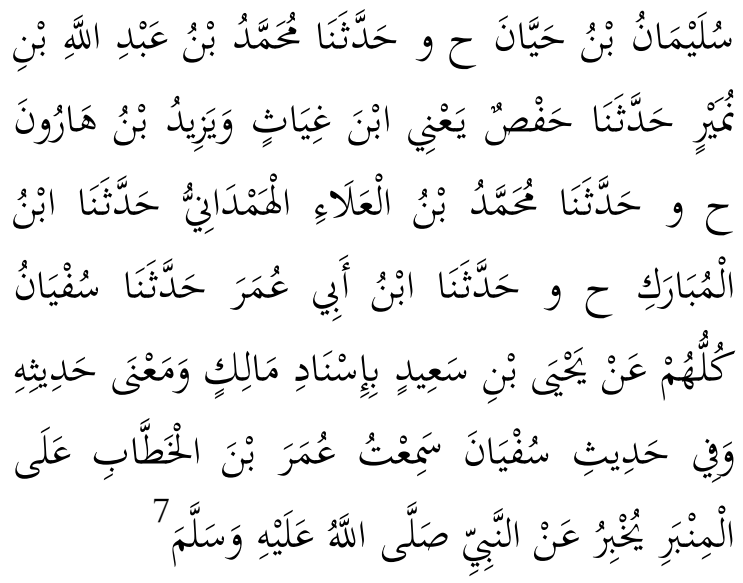

"Telah menceritakan kepada kami Abdullah bin Maslamah bin Qa'nab telah menceritakan kepada kami Malik dari Yabya bin Sa'id dari Mubammad bin Ibrabim dari 'Alqamah bin Waqash dari Umar bin Khattab dia berkata, "Rasulullah shallallabu 'alaibi wasallam bersabda, "Sesungguhnya amalan itu tergantung dengan niatnya, dan sesungguhnya ia akan mendapatkan sesuatu yang diniatkannya, barangsiapa hijrahnya untuk Allah dan Rasul-Nya, maka hijrahnya untuk Allah dan RasulNya, dan barangsiapa hijrahnya untuk memperoleh dunia atau seorang wanita yang akan dinikahinya, maka hijrahnya sesuai dengan apa yang diniatkannya." Dan telah menceritakan kepada kami Mubammad bin Rumb bin Mubajir telah mengabarkan kepada kami Laits. (dalam jalur lain disebutkan) Telah menceritakan kepada kami Abu Ar Rabi' Al Ataki telah menceritakan kepada kami Hammad bin Zaid. (dalam jalur lain disebutkan) Telah menceritakan kepada kami Mubammad bin Al Mutsanna telab menceritakan kepada kami Abdul Wabhab -yaitu Ats Tsaqafi-. (dalam jalur lain disebutkan) Telah menceritakan

7 Al-Imam Abi Al-Husain Muslim bin AlHajjaj ibn Muslim Al-Qusairi Al-NaisaburiAlNaisaburi, Al-Jami' al-Shahih (Bairut: Dar al-Fikr, t.t), p. 48. kepada kami Ishaq bin Ibrabim telab mengabarkan kepada kami Abu Khalid Al Abmar Sulaiman bin Hayyan. (dalam jalur lain disebutkan) Telah menceritakan kepada kami Muhammad bin Abdullab bin Numair telah menceritakan kepada kami Hafsh -yaitu Ibnu Gbiyats- dan Zaid bin Harun. (dalam jalur lain disebutkan) Telah menceritakan kepada kami Mubammad bin Al 'Ala Al Hamdani telab menceritakan kepada kami [Ibnu Mubarak. (dalam jalur lain disebutkan) Telah menceritakan kepada kami Ibnu Abu Umar telah menceritakan kepada kami Sufyan semuanya dari Yabya bin Sa'id dengan sanad makna seperti riwayat Malik. Dan dalam hadisnya Sufyan disebutkan, 'Saya mendengar Umar bin Khattab di atas mimbar mengabarkan dari Nabi shallallabu 'alaibi wasallam."

\section{Hadis Riwayat Abu Daud}

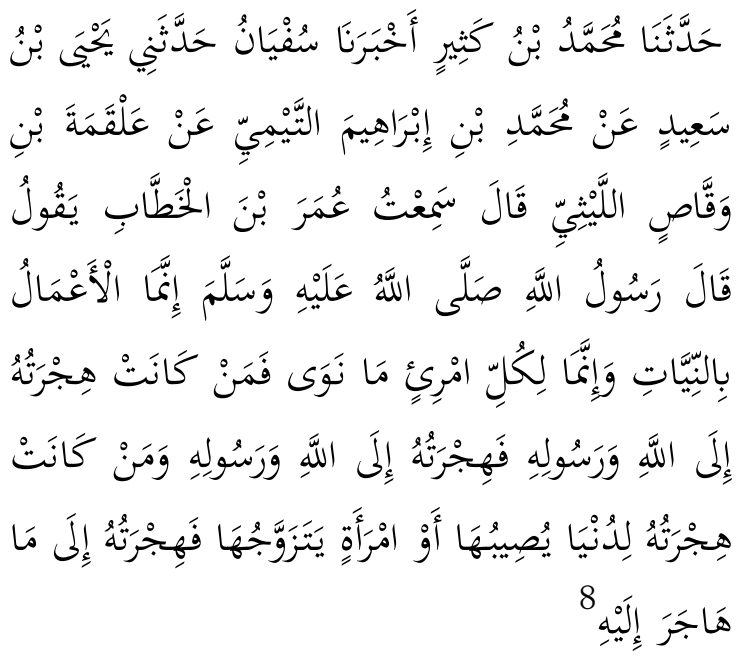

"Telah menceritakan kepada kami Mubammad bin Katsir, telah mengabarkan kepada kami Sufyan, telah menceritakan kepadaku Yabya bin Sa'id dari Mubammad bin Ibrabim At Taimi dari 'Alqamab bin Waqqash Al Laitsi, ia berkata; aku mendengar Umar bin $A l$

${ }^{8}$ Sulaiman bin Al-Asy ${ }^{\text {ee }}$ ats bin bin Syaddad bin Amr bin Amir Abu Daud, Sunan Abu Daud (Bairut: Dar al-Fikr, t.t), III, h. 235. 
Khathab berkata; Rasulullah shallallabu 'alaibi wasallam bersabda, "Sesungguhnya amalan itu tergantung kepada niatnya, dan bagi setiap orang akan mendapatkan sesuai apa yang telah ia niatkan. Barangsiapa yang hijrahnya kepada Allah dan RasulNya, maka hijrahnya adalah kepada Allah dan RasulullahNya, dan barang siapa yang hijrahnya untuk dunia yang hendak ia dapatkan atau karena seorang wanita yang akan ia nikahi, maka hijrahnya akan mendapatkan sesuai apa yang ia maksudkan."

\section{Hadis Riwayat An-Nasai}

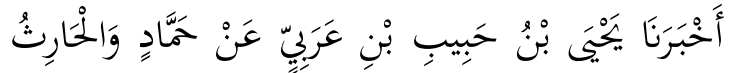

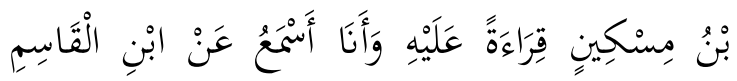

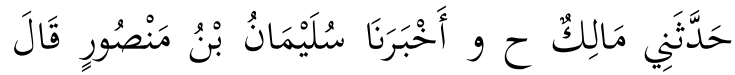

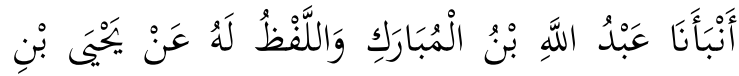
سَعِيدٍ عَنْ عُحَمَّدِ بْنِ إِبْرَاهِيمَ عَنْ عَلْقَمَةَ بْنِ وَقََّصِ

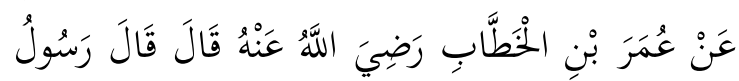

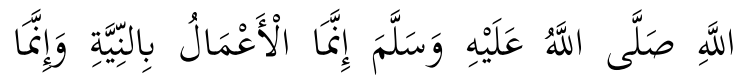

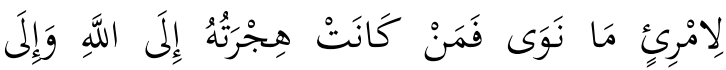

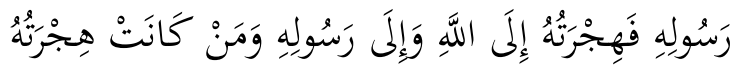

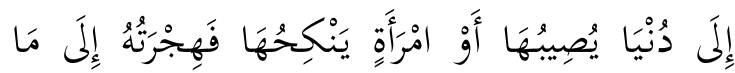
هَاجَرَ إلَيْهِهِ

"Telah mengabarkan kepada kami Yabya bin Habib bin 'Arabi dari Hammad dan Al Harits bin Miskin telab dibacakan kepadanya dan saya mendengarnya dari Ibnu Qasim telah menceritakan kepadaku Malik telah menceritakan kepada kami Sulaiman

9 Al-Imam Al-Hafidz Abd Al-Rahman Ahmad bin Syu'aib bin Ali bin Sinan bin Bahr bin Dinar AlKharasani an-Nasai, Sunan Al-Kubra (Mesir: Dar alKutub al-Ilmiyah, t.t), I, h. 89. bin Manshur dia berkata; Telah memberitakan kepada kami Abdullah bin Mubarak dan lafazhnya dari dia, dari Yabya bin Sa'id dari Mubammad bin Ibrabim dari Al Qomah bin Waqqash dari Umar bin Khatthab Radliyallahu'anbu, dia berkata; Rasulullah shallallahu 'alaibi wasallam bersabda, "Semua perbuatan tergantung niat, dan (balasan) bagi tiap orang (tergantung) yang diniati, barangsiapa berniat hijrahnya karena Allah dan Rasul-Nya, maka hijrahnya kepada Allah dan Rasul-Nya. Barangsiapa niat hijrahnya karena dunia yang ingin digapai atau karena seorang perempuan yang ingin dinikahi, maka hijrahnya sekedar yang diniatinya."

\section{E. Hadis Riwayat Ibnu Majah}

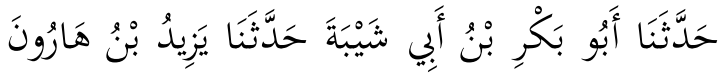

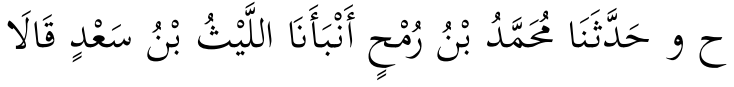

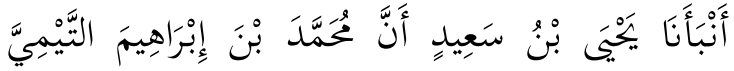

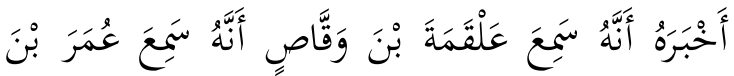

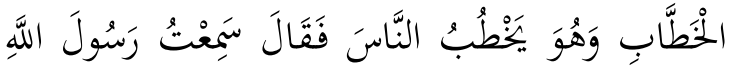

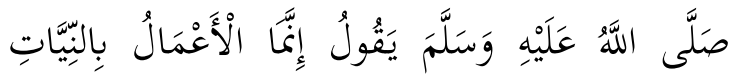

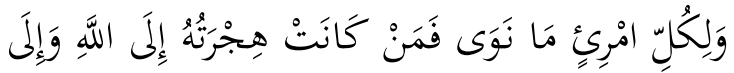

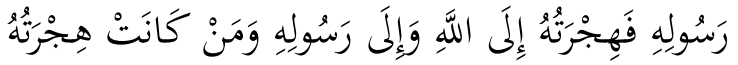

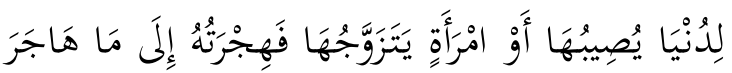

"Telah menceritakan kepada kami Abu Bakar bin Abu Syaibah telah menceritakan kepada kami Yazid bin Harun. Dan diriwayatkan dari jalur lain, telah

10 Muhammad bin Yazid Ar-Raba'i AlQazwini Majah, Sunan Ibn Majah (Bairut: Dar al-Fikr, t.t), II, h. 570 . 
menceritakan kepada kami Mubammad bin Rumb telah memberitakan kepada kami Al Laits bin Sa'd Keduanya berkata; telab memberitakan kepada kami Yabya bin Sa'id bahwa Mubammad bin Ibrabim At Taimi telab mengabarkan babwa dia pernab mendengar' Alqamah bin Waqash bahwa dia mendengar Umar bin Khatthab sedang berkhotbah di hadapan manusia, katanya; "saya pernah mendengar Rasulullah shallallabu 'alaibi wasallam bersabda: "Sesungguhnya setiap amalan sesuai dengan niat, dan balasan bagi seseorang itu sesuai dengan apa yang di niatkannya. Maka barangsiapa hijrahnya untuk Allah dan Rasul-Nya maka pahala hijrahnya karena Allah dan Rasul-Nya, dan barangsiapa hijrahnya untuk dunia atau wanita yang akan di nikahinya, maka balasan hijrahnya sesuai dengan tujuan hijrahnya tersebut."

\section{SYARAH HADITS DAN FIKIH NIAT}

Sebagian riwayat menggunakan lafaz لنية dalam bentuk mufrad (tunggal) dengan alasan, bahwa tempat niat adalah dalam hati, sedangkan hati itu satu, maka kata niyat disebutkan dalam bentuk tunggal. Berbeda dengan perbuatan yang sangat tergantung kepada hal-hal yang bersifat lahiriah yang jumlahnya sangat banyak dan beragam, sehingga dalam hadis tersebut kata 'amal menggunakan lafaz jama' (plural) yaitu ان اعمال selain itu niat hanya akan kembali kepada Dzat Yang Esa, dan tidak ada sekutu bagi-Nya. ${ }^{11}$ Sebagai kelanjutan dan ikrar dari niat. Al-A'mal mencakup berbagai bentuk perbuatan, baik perbutan hati, lisan, dan jawarih (anggota badan). Amal hati seperti

${ }^{11}$ Ibnu Hajar al-Asqalani, 'Fathul Baari Syarah Shahih Bukhari (Gazirah Abdi Ummah Terj.)', Jakarta: Pustaka Azam, 2002, p. 18. tawakkal kepada Allah, kembali dan takut kepadaNya. Amal lisan seperti berbicara dan makan. Amal jawarih seperti perbuatan tangan dan kaki dan yang semisalnya. Sedangkan af'al yaitu perbuatan yang tidak menekankan pada nilai-nilai dihadapan Allah, dan terkadang perbuatan dilakukan tanpa niat terlebih dahulu.

Lafaz إنَّمَا ألْعَمَالُ بِالنَّيَّاتِ mengandung arti hashr (pembatasan) menurut para muhaqqiq (peneliti). Setiap perbuatan pasti membutuhkan pelaku, maka kalimat secara lengkap adalah perbuatan yang berasal dari orang-orang mukallaf (orang yang dikenai beban syariat). Dengan demikian apakah perbuatan orang kafir termasuk dalam kategori ini? Jawabnya, tidak termasuk, karena maksud perbuatan dalam hadis ini adalah ibadah, sehingga orang kafir tidak termasuk dalam hadis ini, meskipun mereka diperintahkan untuk melaksanakan dan akan mendapat hukuman apabila meninggalkannya.

Kata بِالنَيَّاتِ (dengan niat). Huruf ba' menunjukkan arti mushababah (menyertai), dan ada juga yang mengartikan sababiyah (menunjukkan sebab). Imam Nawawi mengatakan, bahwa niat berarti maksud, yaitu keinginan yang ada dalam hati. Tetapi Syaikh Al-Karmani menambahkan, bahwa keinginan hati adalah melebihi maksud. Alqashd atau maksud adalah bagian dari suatu kehendak atau al-iradah yang kekuatannya bisa mencapai kekeinginan kuat, sedangkan kehendak itu tidak akan sampai pada keinginan ketika tidak ada suatu kepastian dalam berkehendak, namun keinginan dapat berubah-ubah terkadang kuat terkadang lemah, adapun maksud itu dapat terwujud ketika adanya kehendak yang bersifat pasti adalah yang beriringan atau bersamaan dengan suatu tindakan. Oleh karena itu, para 
ulama berpendapat bahwa niat harus diiringi dengan pekerjaan yang telah diniatkan. ${ }^{12}$

\section{PENGARUH NIAT TERHADAP MOTIVASI DAN IMPLIKASINYA BAGI PESERTA DIDIK}

Hadis tentang niat ini merupakan salah satu dari hadis-hadis yang menjadi inti ajaran Islam. Imam An-Nawawi mengatakan bahwa kaum muslimin telah berijma' akan keagungan kedudukan hadis ini dan banyaknya faidah-faidah serta keabsahannya. Imam Ahmad dan Imam Syafi'i mengungkapkan bahwa hadis tentang niat ini mencakup sepertiga ilmu. Hal ini karena perbuatan hamba terdiri dari perbuatan hati, lisan dan anggota badan, sedangkan niat merupakan salah satu dari ketiganya. ${ }^{13}$ Sejumlah ulama bahkan ada yang berpendapat bahwa hadis ini merupakan sepertiga Islam.

Niat tidak hanya sebagai ikrar atau tekad untuk melakukan sesuatu melainkan pula harus diiringi dengan melakukan niat tersebut. Sering terdengar kalimat, "yang penting kan niat" di kalangan masyarakat awam dan seakan hanya menggampangkan saja untuk urusan niat ini. Sebanarnya, hal ini termasuk keliru dan salah kaprah dalam pengunanaan dalil niat. Butuh pemahaman secara utuh terhadap kajian tentang niat sesuai dengan petunjuk dari Al-Qur'an, yaitu dalam kerangka bimbingan ilahi yang pasti benarnya dan tak diragukan keadilannya. Allah berfirman dalam surat Al-An'am: 115: "Dan telah sempurnalab kalimat Tubanmu, dalam kebenaran dan keadilan-Nya. Tidak ada yang dapat mengubah-ubah kalimat-Nya. Dan Dialah yang Maha Mendengar lagu Maba Mengetahui".

12 Umar Sulaiman, 'Fiqih Niat', Jakarta: Gema Insani, 2006.

13 Ayep Rosidi, 'Niat Menurut Hadis Dan Implikasinya Terhadap Proses Pembelajaran', INSPIRASI: Jurnal Kajian Dan Penelitian Pendidikan Islam, 1.1 (2017), 39-50.
Imam An-nawawi mengatakan bahwa jumhur ulama dari ahli bahasa dan ushul serta selain mereka berkata "lafadz niyyati berfungsi sebagai pembatasan yaitu menetapkan yang disebutkan dan meniadakan yang tidak disebutkan." Jadi maksudnya adalah sah atau tidaknya amal perbuatan suatu ibadah itu tergantung pada niatnya. Imam al-Nawawi berkata, "Sesungguhnya amal perbuatan itu diberi pahala berdasarkan niat dan tidak akan diberi pahala jika (amal perbuatan tersebut tanpa niat."

Hadis tentang niat ini akan sangat mempengaruhi motivasi para peserta didik karena niat sangat diperlukan dalam proses pembelajaran. Oleh karena itu niat dan motivasi belajar secara bersamaan juga dapat berdampak terhadap hasil belajar. ${ }^{14}$ Sehingga Islam menekankan agar ketika menuntut ilmu azamkanlah semata-mata karena Allah dan dengan tujuan tertentu sesuai dengan cita-cita yang ingin diraih. Bahkan, Imam Abdurrahman bin mahdi sangat menganjurkan dan memberi peringatan bagi penuntut ilmu agar memperbaiki niatnya. Sesungguhnya peserta didik yang memiliki motivasi belajar yang tinggi, berlandaskan kepada niat dan dorongan untuk belajar semata-mata untuk memenuhi tuntunan agama akan berpotensi untuk lebih berhasil karena segala upayanya disertai oleh ridha dari Allah. Motivasi dan niat sebenarnya timbul dari dalam diri manusia karena terbukanya hati manusia karena hidayah Allah sehingga seseorang tersebut menjadi seorang yang memiliki iman kemudian dengan iman itu lahirlah tingkah laku keagamaan karena adanya niat, motivasi dengan iman tersebut.

Beberapa peran motivasi dalam kehidupan sangat banyak di antaranya :

1. Sebagai pendorong seseorang melakukan sebuah tujuan, keinginan ataupun cita-

${ }^{14}$ Emda. 
cita sehingga tindakan yang di lakukan untuk mencapai tujuan tersebut terarah.

2. Sebagai penguji sikap seseoang dalam beramal benar atau salah, ia dapat menyeleksi mana yang sehrusnya ia lakukan dan masih banyak peran lainnya. ${ }^{15}$

Maka seperti yang telah dituliskan sebelumnya konsep niat sangat berpengaruh dan penting dalam proses pembelajaran, dimana pembelajaran sangat penting untuk kelangsungan kehidupan manusia dalam perkembangan zaman. Berkenaan dengan itu maka kesadaran kritis untuk menumbuhkan motivasi niat maupun minat seseorang untuk belajar juga sangat diperlukan. Berkaitan dengan itu perlu diketahui bagaimana caranya untuk membangun kesadaran yang kritis tersebut? Madrasah atau sekolah merupakan wadah pendidikan untuk menciptakan manusia yang cerdas kritis sekaligus juga memberikan peserta didik pilihan untuk menjadi pelaku utama, atau sasaran dari sebuah pendidikan. Maknanya peserta didik harus lebih berperan aktif untuk mencari pengetahuan dan menentukan apa yang ingin ia pelajari, karena dalam pembelajaran masa kini guru bukanlah satu-satunya sumber untuk mendapatkan ilmu, sumber informasi ilmu bisa didapatkan peserta didik dari lingkungan yang ada disekitarnya maupun dari perkembangan tekhnologi informasi ketika ini yang dapat diakses peserta didik bila dan dimana saja, menyadari kondisi nyata tersebut maka kecendrungan dalam pembelajaran harus menyesuaikan dengan perubahan paradigma dimana saatnya guru mesti dapat memposisikan dirinya sebagai pengajar sekaligus pendidik, sebagai orang tua di sekolah, sebagai fasilitator dan juga

15 Purwanto, "Motivasi Belajar Dalam Pendidikan Islam,” n.d., h. 222-224. ada kalanya sebagai teman tempat peserta didik meluahkan isi hatinya.

Motivasi dan belajar adalah dua hal yang tidak dapat dipisahkan diibaratkan seperti dua sisi mata uang yang masingmasing sisi memiliki nilai yang berharga, jika salah satu dari masing-masing sisi tersebut tidak ada gambarannya maka tiada berarti kepingan uang tersebut, Mengapa siswa berkinginan untuk belajar sungguh-sungguh tentu ada motivasi tertentu yang ingin dicapai, sebaliknya mengapa ada motivasi tentunya ada motif tertentu juga yang mendasarinya, untuk mewujudkannya pembelajaran sebagai wahananya. Sebab itu, dalam kegiatan belajar faktor motivasi sangat diperlukan untuk mendukung kelancaran dan antusiasisme belajar siswa. Belajar yang dilandasi oleh motivasi yang kuat akan membuahkan hasil belajar yang sempurna meliputi penguasaan dan pemahaman seperangkat pengetahuan (aspek kognitif), sikap dalam tatanan nilai akhlakul karimah (Afektif) serta kecakapan hidup (psikomotorik) plus kemampuan hidup bersama saling pengertian dan mampu bekerjasama dalam kebaikan (life together).

Di bawah ini merupakan beberapa ciri dari pembelajaran yang dapat membangun kesadaran kritis, yaitu:

1. Sebuah proses pembelajaran berdasarkan realitas dan fakta atau pengalaman, maksudnya yang di pelajari siswa dalam sebuah pembelajaran bukanlah sematamata ajaran yang bersifat verbalis (teori, pendapat, kesimpulan, ataupun wejangan), tetapi sebuah kenyataan, keabsahan sebuah pengetahuan atau ilmu yang diwujudkan dengan sebuah bukti berupa pengalaman, pengetahuan dan tindakan langsung bukan sebatas teoritik belaka.

2. Tidak menggurui, meskipun tidak terbatahkan guru perannya sangat esensial sebagai subjek dalam 
pembelajaran, melainkan maksudnya guru dan murid berlaku sama, sama-sama belajar karena terkadang guru ada yang belum mengetahu suatu hal dan murid telah mengetahui, begitu pula sebaliknya murid belajar dari pengalaman dan pengetahuan guru.

3. Dialogis, maksudnya proses pembelajaran methode yang digunakan bukan hanya komunikasi bersifat satu arah harus hanya terfokus pada guru saja namun lebih diarahakan adanya interaksi dua arah antara guru dengan peserta didik bahkan dapat berbentuk multi arah dalam bentuk diskusi, menggunakan media, alat peraga dan lain sebagainya yang memungkinkan terjadinya dialog kritis anata semua orang bukan hanya beberapa orang.

4. Pembelajaran dapat menarik sebuah kesimpulan dari segenap materi yang ditransformasikan kepada siswa, sehingga akan dapat lebih mudah dipahami dan diaplikasikan oleh peserta didik, tidak hanya sebatas untuk kepentingan evaluasi saja namun bermanfaat dalam hidup dan kehidupan mereka.

5. Pembelajaran hendaknya dapat menimbulkan sebuah tindakan yakni dengan kesadaran berfikir kritis tersebut untuk menerapkan apa yang telah di dapat dari sebuah proses pembelajaran tersebut yang telah di simpulkan sehingga dalam melakukan tindakan dalam berfikir kritis tersebut dapat memberi pengetahuan dan pengalaman baru, sehingga kesadaran berfikir kritis juga tentu akan berpengaruh dalam membangun niat seseorang untuk belajar. ${ }^{16}$

16 D. M. Elika, 'Peran Guru Dalam Membangun Kesadaran Kritis Siswa', Jurnal Pendidikan Penabur-No, 6 (2006).

\section{KESIMPULAN}

Dari uraian-uraian di atas yang mendeskripsikan tentang niat menurut hadis dan implikasinya terhadap proses pembelajaran dapat ditarik beberapa kesimpulan sebagai berikut. Pertama, hadis yang disebutkan di atas memiliki kualitas sahih, baik dari segi sanad maupun matan, karena semua kriteria kesahihan termasuk bersambungnya sanad, perawinya 'adil dan dhabit, semuanya terpenuhi, bahkan apabila semua riwayat yang terkait semakna dengan hadis di atas dikaitkan maka kualitasnya akan semakin kuat karena hadis-hadis tersebut saling mendukung antara satu dengan yang lain. Kedua, hadis dalam kajian ini merupakan salah satu dalil yang menunjukkan pentingnya niat dalam segala amal yag dilakukan agar bernilai pahala. Ketiga, apapun yang dikerjakan tergatung pada niatnya, dan semua konsekuensi yang didapat merupakan buah dari niat awal. Keempat, niat dan motivasi secara bersamaan dapat berdampak terhadap hasil belajar, sehingga, tinggi rendahnya hasil belajar siswa ditentukan oleh tinggi rendahnya motivasi belajar. Peserta didik yang memiliki motivasi belajar yang tinggi, berlandaskan kepada niat dan dorongan untuk belajar semata-mata untuk memenuhi tuntunan agama berpotensi untuk lebih berhasil karena segala upayanya disertai oleh ridha dari Allah.[]

\section{DAFTAR PUSTAKA}

Abu Daud, Sulaiman bin Al-Asy'ats bin bin Syaddad bin Amr bin Amir, Sunan Abu Dand (Bairut: Dar al-Fikr, t.t), III

Al-Bukhari, Muhammad bin Isma'il bin Ibrahim, Shabih Al-Bukhari (Riyadh: Dar as-Salam, 1999), I

Al-NaisaburiAl-Naisaburi, Al-Imam Abi AlHusain Muslim bin Al-Hajjaj ibn 
Muslim Al-Qusairi, Al-Jami' al-Shabih (Bairut: Dar al-Fikr, t.t)

al-Asqalani, Ibnu Hajar, 'Fathul Baari Syarah Shahih Bukhari (Gazirah Abdi Ummah Terj.)', Jakarta: Pustaka Azam, 2002

Assa'idi, Sa'dullah, 'Hadis-Hadis Sekte', Yogyakarta: Pustaka Pelajar, 1996

Elika, D. M., 'Peran Guru Dalam Membangun Kesadaran Kritis Siswa', Jurnal Pendidikan Penabur-No, 6 (2006)

Emda, Amna, 'Kedudukan Motivasi Belajar Siswa Dalam Pembelajaran', Lantanida Journal, 5.2 (2018), 172-82

Majah, Muhammad bin Yazid Ar-Raba'i AlQazwini, Sunan Ibn Majah (Bairut: Dar al-Fikr, t.t), II

an-Nasai, Al-Imam Al-Hafidz Abd AlRahman Ahmad bin Syu'aib bin Ali bin Sinan bin Bahr bin Dinar AlKharasani, Sunan Al-Kubra (Mesir: Dar al-Kutub al-Ilmiyah, t.t), I

Rosidi, Ayep, 'Niat Menurut Hadis Dan Implikasinya Terhadap Proses Pembelajaran', INSPIRASI: Jurnal Kajian Dan Penelitian Pendidikan Islam, 1.1 (2017), 39-50

Soebahar, HM Erfan, Menguak Fakta Keabsahan Al-Sunnab (Prenada Media, 2003)

Sulaiman, Umar, 'Fiqih Niat', Jakarta: Gema Insani, 2006 